\title{
Seasonal fluctuations of Ixodes persulcatus and adult stage of Ixodes ovatus in the subalpine forests of Nagano Prefecture, Japan, related to observed phenological data (Acari, Ixodidae) *
}

\author{
Kimito UGHIKAWA ** \\ Department of Parasitology, Shinshu University School of Medicine, \\ Matsumoto 390, Japan
}

(Received: December 18, 1992)

Key words: seasonal fluctuation, I. persulcatus, I. ovatus, subalpine forest, phenological datum.

\begin{abstract}
The seasonal fluctuations of immature and adult 1 . persulcatus and adult $I$. ovatus were studied by flagging vegetation in the subalpine forests of Konashidaira and Sanjiro, Nagano Prefecture. The flaggings were conducted over the period from April to October. 1991, as well as, supplementally, the same period in 1992. The adult, nymph and larva of $I$. persulcatus showed a biannual fluctuation in number with a large peak from the end of May to the middle of June and a small one in the fall. The 1991 autumnal peak of the adult of $I$. persulcatus was so small that it was only represented by a single specimen per 100 sweepings. Adults of $I$. ovatus appeared during the time spanning mid April to mid October. The seasonal fluctuation in the number of adult $I$. ovatus was not as remarkable as was that of adult $I$. persulcatus. Adult $I$. ovatus occurred in large numbers in the period between the end of May and middle of July and again in the end of August. Both of tick species were most abundant during the period when a number of overwintered butterflies were observable. Seasonal highs of the two tick species also coincided with the time when some butterflies and flowers, both part of the scenic attractions of Konashidaira and Sanjiro, were in season contiguously.
\end{abstract}

\section{INTRODUCTION}

Ixodes persulcatus Schultze and Ixodes ovatus Neumann are of great concern to

* The supplementary survey in 1992 was supported financially in part by Grant-in-Aid for Scientific Research (No. 04671391) from the Ministry of Education, Science and Culture, Japan.

** 内川公人：信州大学医学部寄生虫学教室（兵390 松本市旭 3-1-1)
Japanese medical acarologists in that both species are infected with Borrelia burgdorferi, the etiologic agent of Lyme borreliosis and its relatives. Everywhere that the two have been examined for the spirochetes, rather high rates of spirochete infection have been found (Ishiguro et al., 1992; Miyamoto et al., 1991, 1992a, b; Nakao et al., 1992; Uchikawa et al., 1991). Since the seasonality of an arthropod-born disease depends completely on the seasonal activities of its vector(s), the fluctuations of $I$. persulcatus and I. ovatus 
should be studied thoroughly throughout a year's cycle for the epidemiology of Lyme borreliosis as well as for the acquisition of material for diverse experiments.

I. persulcatus and I. ovatus, both common and widely distributed species in Japan, often bite humans (Horiuchi and Ando, 1987; Miyamoto and Nakao, 1991; Nakama et al., 1991; Yamaguti, 1989; Yamaguti et al., 1971). Consequently, the seasonal fluctuations of these ticks have been investigated by many workers (Fujimoto et al., 1987; Fujimoto and Yamaguti, 1990; Miyamoto and Nakao, 1991; Saito, 1959; Uchikawa and Sato, 1983). Since the developmental cycle and seasonal activity of a tick may vary according to climatic conditions, as summarized by Arthur (1961) and Balashov (1968), the seasonal fluctuations of $I$. persulcatus and $I$. ovatus should be studied once in regions of distinct climatic conditions. From the scope of preventing human tick bites, it is also necessary to visualize the seasonality of problematic ticks in relation to more easily perceived phenomena, i.e., the seasons of attractive insects and/or plants and the particular human activities affected by them. With these two demands in mind, I conducted a survey of the seasonal fluctuations of $I$. persulcatus and $I$. ovatus ticks in the subalpine forests in Nagano Prefecture in 1991 and, supplementally, in 1992, using the flagging method.

\section{SAMPling Method AND Survey Sites}

The flag, consisting of a $0.7 \mathrm{~m} \times 1 \mathrm{~m}$ flannel cloth with a bamboo bar hemmed along its shorter margin, was swept across low herbaceous vegetation for about $2 \mathrm{~m}$ at a time. All ticks on both sides of the flag were collected after each sweeping. Collections were planned to be made every three weeks from April to October, 1991, though the interval was obliged to change due to weather conditions. Each collection constituted 100 sweepings.

Konashidaira, Kamikochi, at $1,500 \mathrm{~m}$ above sea level in the Chubu (Central Japan)
Alpine National Park, was selected as the survey site for all stages of $I$. persulcatus. Konashidaira is the flat land formed between the Azusa River and its steep southern mountains. This area is covered with a Larix leptolepis-Sasa senanensis community. There is a camping ground, usually strewn with many private and rental tent houses in the summer season. At the opposite side of a stream, there is a camping village comprising many rental lodges along unpaved, 3-m wide roads where Plantago asiatica grows. Fifty sweepings were made at each collection time, respectively, on both the edge of the grassy parts of the camping ground and the roads covered with $P$. asiatica in the camping village.

Sanjiro, on a western slope of Utsukushigahara Mountains, was selected as the survey site for adult $I$. ovatus as well as for nymphs and adults of $I$. persulcatus. Along a stream between Sanjiro and Hirokoba, at 1,400$1,500 \mathrm{~m}$ above sea level, there is a small-scale subalpine forest consisting mainly of Abies veitchii and a hiking trail. At around $1,600 \mathrm{~m}$ above sea level, there is a man-made L. leptolepis forest and trail to Mt. Chausu. Although the floor of the forest is covered densely with $S$. senanensis, $P$. asiatica grows both sparsely and densely in places on the trail. At each collection time, 50 sweepings were made across the vegetation, respectively, along the sides of the trail at 1,400-1,500 m and on the trail at approximately $1,600 \mathrm{~m}$. There was surface water in three or four places on both trails.

Some phenological data and human seasonal activities were noted, if any, during each collection time.

To supplement the data on the larvae and adults of $I$. persulcatus, additional surveys were carried out at Sanjiro early in June, toward the end of September, and early in October, 1992. In these supplementary surveys, as many ticks as possible were taken without counting the number of sweepings along the course used in 1991. Some very low or sparse herbaceous vegetation off the course was sometimes swept for locating larvae. 
Vol. 44 No. 31993

Table 1 Numbers of Ixodes persulcatus and I. ovatus per 100 sweepings.

Konashidaira, Kamikochi, 1991

\begin{tabular}{lccccccccc}
\hline \hline & \multicolumn{10}{c}{ Date } & & \\
\cline { 2 - 7 } & V.7 & V.29 & VI. 18 & VII. 15 & VIII.9 & IX. 2 & IX. 23 & X. 16 & Total \\
\hline $\begin{array}{l}\text { I. persulcatus } \\
\text { Male }\end{array}$ & 5 & 49 & 43 & 10 & 0 & 0 & 1 & 0 & 108 \\
Female & 4 & 45 & 44 & 5 & 1 & 0 & 0 & 0 & 99 \\
Total & 9 & 94 & 87 & 15 & 1 & 0 & 1 & 0 & 207 \\
Nymph & 4 & 116 & 68 & 23 & 3 & 0 & 5 & 3 & 222 \\
Larva & 0 & 71 & 162 & 16 & 0 & 0 & 119 & 49 & 417 \\
\hline
\end{tabular}

Sanjiro, Utsukushigahara Mountains, 1991

\begin{tabular}{|c|c|c|c|c|c|c|c|c|c|c|}
\hline & \multicolumn{9}{|c|}{ Date } & \multirow{2}{*}{ Total } \\
\hline & IV. 17 & V. 7 & V. 30 & VI. 18 & VII. 9 & VII. 31 & VIII. 26 & IX. 17 & X. 14 & \\
\hline \multicolumn{11}{|c|}{ I. persulcatus } \\
\hline Male & 7 & 10 & 51 & 23 & 10 & 5 & 1 & 0 & 0 & 107 \\
\hline Female & 5 & 16 & 71 & 32 & 12 & 5 & 0 & 0 & 0 & 141 \\
\hline Total & 12 & 26 & 122 & 55 & 22 & 10 & 1 & 0 & 0 & 248 \\
\hline Nymph & 6 & 3 & 26 & 8 & 3 & 3 & 0 & 0 & 0 & 49 \\
\hline \multicolumn{11}{|l|}{ I. ovatus } \\
\hline Male & 0 & 1 & 17 & 22 & 12 & 5 & 6 & 7 & 2 & 72 \\
\hline Female & 1 & 0 & 15 & 14 & 23 & 7 & 23 & 7 & 0 & 90 \\
\hline Total & 1 & 1 & 32 & 36 & 35 & 12 & 29 & 14 & 2 & 162 \\
\hline
\end{tabular}
Only a single male $I$. ovatus was taken at Konashidaira on June 18 , and no larvae were recorded at
Sanjiro in 1991 .

\section{Results}

The dates of the collections and the numbers of ticks collected in 1991 are given in Table 1. To visualize the seasonal fluctuations of the two species more clearly, the data are depicted again in Fig. 1.

\section{I. persulcatus}

At Konashidaira, Kamikochi, nymphs and adults were taken from May 7 to August 8 and, again, in the fall. Both stages were scarce in early May but became abundant toward the end of May. Adults continued to be abundant on June 18 but nymphs distinctly decreased in number at this time. From
July to early August, adults and nymphs were taken but were not so abundant. In the fall, one adult male was taken on September 23, and five and three nymphs were found on September 23 and October 16, respectively. Larvae were first found at the end of May, and then showed a peak in abundance on June 18. This stage was obtainable until mid July, and again in late September and mid October. As many as 119 larvae were taken on September 23, the majority of which were swept up in a single sweeping. On the whole, 108 males, 99 females (sex ratio 1.09), 222 nymphs, and 417 larvae were taken during the survey.

At Sanjiro, in the Utsukushigahara Mountains, nymphs and adults were found as early 




Fig. 1 Per cent catch at each collection time in 1991.

K: Konashidaira, Kamikochi; U: Sanjiro, Utsukushigahara Mountains. ND, not done. IP, I. persulcatus; IO, I. ovatus; A, adult; $\mathrm{N}$, nymph; L, larva. $n$ : total number of ticks caught in 1991. F, Female; M. Male.

as mid April. Thereafter, their seasonal fluctuations were similar to those of nymphs at Konashidaira, i.e., with a peak in abundance at the end of May followed by a decrease in number toward the end of July. Only a single male was found in late August. No larvae were recorded during the survey in 1991. A total of 107 males, 141 females (sex ratio 0.76), and 49 nymphs were collected in 1991.

\section{I. ovatus}

Only a single male was taken on Konashidaira on June 18. All other males and/or females were taken at Sanjiro. There were only a few ticks in mid April and early May, and though they became abundant late in May they were again less so in October. A mere maximum of $22.2 \%$ of the total ticks for the year was taken at a single time, in contrast to a maximum of more than $40 \%$ caught during the peak in abundance of I. persulcatus (Fig. 1). During July and August, ticks were frequently taken near the surface water in wet places. This tendency was not seen in $I$. persulcatus, though they were scarce in July and August. On Sanjiro, a total of 162 adults, consisting of 72 males and 90 females (sex ratio 0.80 ), were taken in 1991.

\section{Phenological data and human activities}

On April 17, when snow was thereabouts, a few sprouts of coltsfoot (Petasites japonicus) were barely apparent, and only the butterflies (Gonepteryx machaguru and Nymphalis antiopa) that had wintered nearby were observable at Sanjiro. The route to Kamikochi was closed until the end of April. On May 7, some spring flowers (P. japonicus and Anemone flaccida) began to bloom, and a newly emerged butterfly (Pieris sp.) was noticed among the many wintered ones (Aglais urticae) at Konashidaira. At this same time, the early spring papilionid, Luedorfia puziloi, was observed and Potentilla freyniana was in full bloom at Sanjiro. At the end of May, males of Anthocharis cardamines (orange tip) were seen, and $A$. flaccida was in full bloom at Konashidaira. Moreover, Clintonia udensis and Malus sieboldii were in full bloom, and some favorite wild vegetables were ready for the picking at Sanjiro. On June 18, many rental camping tents had been pitched all together around a part of the survey site at Konashidaira, but no tents were as yet occupied. At this time, Rhododendron japonicum was in bloom, and the overwintered butterfly, $N$. antiopa, was seen for the last time at Sanjiro. Some workers were seen trimming both sides of the trail for hikers on the same date at Sanjiro. In July, pupils of elementary schools and students of junior high schools were camping in groups at Konashidaira and Sanjiro. On August 9, Kamikochi was crowded with visitors. On August 26, at Sanjiro, newly emerged nymphalid butterflies were observed to have remarkably increased in number. By October 14 , fallen leaves were covering the trail at 
Sanjiro.

\section{Supplementary survey at Sanjiro in 1992}

Two hundred and fifty-seven males, 221 females, 43 nymphs, and 2 larvae of $I$. persulcatus, and 24 males and 27 females of I. ovatus, were taken by 3 collectors on June 3. On June 20, 47 males, 55 females, 35 nymphs, and 125 larvae (the majority of which were from a narrow patch of land) of I. persulcatus, and 12 males and 16 females of $I$. ovatus, were taken by 2 collectors. Additionally, 1 female of $I$. persulcatus was found biting the lower left back of a collector in the evening of the same day. On September 22, 1 male, 6 females, 3 nymphs, and 1 larva of $I$. persulcatus, and 24 male and 39 females of $I$. ovatus, were taken by 1 collector. One female of $I$. persulcatus was found biting the left shoulder of a fellow attendant two days later. On October 1, 1 female and 1 nymph of $I$. persulcatus, and 16 males and 27 females of $I$. ovatus, were taken by a single collector.

\section{Discussion}

Many Japanese workers have studied the seasonal fluctuations of $I$. persulcatus and/or I. ovatus. It is clear from their data that sufficient information to discuss the fluctuation was not obtained from their, mainly, unsuitable survey sites. The seasonal changes in relative population densities of ticks can theoretically be obtained anywhere using any sampling method. However, it is difficult to deduce seasonal fluctuations from minute samples. Subsequently, the selection of a survey site is thought to be of primary importance in a study of the seasonal fluctuation of any tick species. When we use a flagging method for sampling ticks, we should keep in mind that there are some deficiencies in this method. The flag easily runs over the top of vegetation, or other kinds of tall and hard obstacles, such that it does not reach low vegetation or the ground, where ticks of immature stages, especially the larvae of $I$. persulcatus, are thought to be questing hosts. Therefore, a site consisting of only low vege- tation is ideal for the study of the immature stages of this species. On the other hand, no immature stages of $I$. ovatus can be caught by the flagging method since they are thought to live underground because of their moisture requirements.

Based on both the above considerations, I selected Konashidaira as the survey site for the adult and immature stages of $I$. persulcatus. Konashidaira had been known to yield such a small number of $I$. ovatus ticks (Uchikawa et al., 1991; and unpublished data) that Sanjiro was added as the other survey site to supplement the data on the adult of $I$. ovatus as well as the adult and nymph of I. persulcatus. As a result, the species and age compositions of the sampled ticks differed by survey site as expected, and (unexpectedly) the sex ratio of $I$. persulcatus did the same. These differences are not related as of yet to characteristics of the survey sites.

A biannual fluctuation was noted in all the adult, nymphal and larval stages of $I$. persulcatus at Konashidaira. No other known author has clearly shown a biannual fluctuation (specifically of the autumnal peak) for adult $I$. persulcatus in Japan, though Yamaguti (1980) noted human tick bite cases caused by this tick species both from May to August and in October. Yamaguti et al. (1971) analyzed the materials obtained on Sado Island, less than $600 \mathrm{~m}$ above sea level, by Saito (1959), and addressed the issue of a biannual fluctuation for adult $I$. persulcatus under the condition that Saito's materials consisted of only $I$. persulcatus and did not include ticks of other species. However, there are some problems to be resolved in Saito's materials before they can be used to deduce seasonal fluctuations in tick populations.

In the present study, the spring-summer fluctuation for adult $I$. persulcatus was mostly explained, but it was difficult to determine how long the spring-summer cohort of the ticks lasted. Adults were continuously taken until August 9 at Konashidaira, whereas they were recorded on both July 31 and August 26 at Sanjiro (Table 1, Fig. 1). Subsequently, a term for the cohort is altered according to which cohort the male specimen taken on 
August 26 belongs. There is no decent evidence to relegate that specimen to a cohort, though very fresh nymphalid wintering butterflies appeared to have had rapidly increased in number on the same date, indicating a phenological change had happened nearby. A sign of some changes within the spring-summer cohort had been noted by a change in the sex ratios in July at both survey sites, though a remarkable difference in sex ratio by survey site is not explicable (Table 1). Ticks of the spring-summer nymphal cohort were taken for the last time on July 31 at Sanjiro and August 9 at Konashidaira, and larvae were last taken on July 15 at Konashidaira (Table 1). Considering these facts, I feel inclined to regard the lone male specimen as one not belonging to the springsummer cohort. Consequently, the springsummer cohort is considered to last until early or mid August. In 1991, the occurrence of adults in the fall was, thus, barely represented by that male specimen and another male taken on September 23 at Konashidaira. In the fall of 1992, some adult specimens were taken with more than 100 sweepings, and a tick bite case caused by $I$. persulcatus was noted at Sanjiro. These data clearly confirm the autumnal occurrence of the adult, although the annual differences in population densities in the fall are to be studied further. It is possible to presume that the autumnal peak for the adult of $I$. persulcatus is so small that it is discernible only when surveys have been cautiously done.

As for nymphs of $I$. persulcatus, numbers were larger than those of adults in the fall, indicating that the autumnal peak is more prominent than in adults. Although nymphs were not found at Sanjiro in the fall of 1991, autumnal specimens of this stage were taken there in 1992.

Larvae of $I$. persulcatus appeared and reached a peak of abundance about three weeks later in the spring than did the adult and nymph at Konashidaira (Table 1, Fig. $1)$. In the fall, a large number of larvae was recorded on September 23, such that the autumnal peak is apparently comparative to the spring-summer one. However, these lar- vae were thought to have been living in a cluster spot since the majority of them were taken by a single sweeping. Consequently, the autumnal peak may be much lower than that depicted in Fig. 1. This might be confirmed by the results of a study previously carried out at Kamikochi, including Konashidaira. In that study, ticks infesting Apodemus speciosus and Apodemus argenteus mice were counted on May 21, July 15 and November 4, 1988, and July 27 and October 13, 1989, and the larval index (larvae/no. of hosts) was much larger in early July than in mid October (unpublished data). This indicates that the spring-summer peak was much higher than the autumnal one. Although no larvae were recorded at Sanjiro in 1991, a considerable number of this stage were timely taken in the supplementary survey in 1992.

Arthur (1961) summarized the seasonal activity of Ixodes ricinus L. in northern England and Scotland in relation to its life cycle, which is thought to be similar to that of I. persulcatus (Balashov, 1968). He clearly showed a biannual fluctuation for females found on both cattle and vegetation. The immature stages reportedly became active in spring subsequent to the adult stage by a fortnight or so in the nymphs and a month in the larvae. The occurrences in the subalpine forests in Nagano Prefecture of the adults and larvae of $I$. persulcatus were almost the same as those of $I$. ricinus as presented by Arthur (1961). However, a subtle delay in appearance in spring was not discernible in the nymphal stage in the present study.

At Sanjiro, I. ovatus ticks were found from spring to autumn, and the numbers of ticks were largest during the period between late May and early July and large again in the end of August. The adult I. ovatus appeared as early as mid April but their numbers raised more slowly than did those of adult $I$. persulcatus in the early spring. Thereafter, a less remarkable seasonal fluctuation in number was noted, as compared to I. persulcatus. A similar survey was once carried out monthly at Hakuba, Nagano Prefecture, $620 \mathrm{~m}$ above 
sea level, where ticks appeared only from April to June and did not do so thereafter (unpublished). This type of uniannual fluctuation for adults of $I$. ovatus has been observed recently by other workers (Fujimoto and Yamaguti, 1990; Fujimoto et al., 1987; Miyamoto and Nakao, 1991). Alternatively, Saito (1959) found female I. ovatus on a natural host throughout the year in Niigata Prefecture, indicating a long-termed activity for this tick. It is proved in the present study that such a long-termed occurrence of adult ticks can be ascertained by the flagging method only when a suitable survey site has been selected. Sanjiro, where very wet places are thereabouts within the collection site, seems to be one such suitable site. However, the nature of the seasonal fluctuation, uniannual or biannual, in such a habitat is not conclusive from the above data (Table 1, Fig. 1). Since the number of ticks taken on July 31 was smaller than those on July 9 and August 26 in 1991, a biannual fluctuation is probable for the adult of $I$. ovatus, too. Had the study been carried out in a site more densely populated by $I$. ovatus, a more remarkable seasonal fluctuation in number might have been shown. As in $I$. ricinus, the exact life cycle of $I$. ovatus should also be studied to determine its seasonal fluctuation.

Only a single male $I$. ovatus was taken at Konashidaira during the survey in 1991. A dearth of $I$. ovatus in the Kamikochi area, including Konashidaira, has been frequently observed by the examination of natural hosts and flagging vegetation (Uchikawa et al., 1991; unpublished data). It is reasonable to presume that some soil environments, inclusive of the moisture of the soil, found at Kamikochi have something to do with this dearth, as is suggested above in the study at Sanjiro.

To prevent human tick bites, we should understand the above seasonal fluctuations of the two main problematic ticks in Japan in relation to seasonal human activities. Both Kamikochi and Sanjiro are popular scenic places that attract many visitors from diverse districts. Human activities in every scenic place rise in accordance with the seasonality of some of its component attractions, such as insects and plants. First of all, it should be remembered that wintered butterflies were observable during the period from mid April to mid June at around $1,500 \mathrm{~m}$ above sea level. This is the same time that both ticks appeared and increased in number to a peak in abundance. During this period, representative attractions such as newly emerged butterflies, beautiful flowers, and wild vegetables were in season one after another. Consequently, visitors who want to watch or collect some of the attractions should be mindful that with their particular objectives come signs of circumferential abundance in ticks ready to bite them. The same phenological phenomena that may occur at different times in different places are also indicative of the season of the ticks. After the above period, the ticks decreased in number gradually at first and, then, rapidly toward early August. We can refer to this period as the second one for the ticks. In the first half of this second period, many pupils and junior high school students go camping or hiking in groups as a school event before summer vacation. In the latter half of the second period, summer vacation begins in both schools and companies, and Kamikochi is crowded with many people. Fortunately, the numbers of both ticks become very small at this time, though they are not negligible. Consequently, rapidly growing numbers of visitors going to camp and hike, and the service workers for them, are likely to be exposed to the dangers of tick bites in the first half of the second period. Other than the nymphalid butterflies as mentioned above, no phenological data were taken in the fall. Many visitors come again to Kamikochi or Sanjiro for about 1 month in mid fall to view crimson the foliage and/or to hunt for mushrooms. However, the numbers of ticks are small and cool ambient temperatures may prevent the movement of ticks in this season. Consequently, the dangers of tick exposure are expected to be not as large in the fall.

Tick bite cases are thought to be common in many places of Nagano Prefecture, inclusive of Kamikochi and Utsukushigahara, 
though it is very difficult to grasp the exact number of annual cases. A total of 26 cases caused by $I$. persulcatus ( 14 females and 2 nymphs), $I$. ovatus (7 females) and Haemaphysalis flava (1 female and 2 nymphs) during the 10 years upto 1990 have been noted (Nakama et al., 1991). All cases reportedly occurred between May and August, with a maximum number in June and July. It has been presumed that the seasonal curve of tick bites was unimodal and that autumnal cases were few. The present study indicates that the immature and adult stages of $I$. persulcatus, and the adult stage of $I$. ovatus, are active again in autumn. Thus, now it can be regarded that autumnal cases of tick bite by respective stages of these two ticks are likely to occur in Nagano Prefecture, though cases are expected to be fewer than those in the spring. It is better to include the larvae of $I$. persulcatus as problematic as a multiple bite caused by larval $I$. ricinus has been reported in Denmark (Hailkier-Sorensen and Kragballe, 1989).

\section{Acknowledgements}

I am grateful to Dr. N. Sato, Hokkaido Institute of Health, Sapporo, for showing me the literature dealing with the multiple incidences of bites by larval $I$. ricinus. The survey at the camping lot of Konashidaira was authorized to be done by the Environment Agency, Japan. Thanks are due to Mr. Masaki Ushiba, the Kamikochi Branch of the agency, Kamikochi, for his pertinent suggestion, and to Mr. Michael Depew, the First Department of Anatomy, Shinshu University School of Medicine, Matsumoto, for improving the manuscript.

\section{REFERENCES}

Arthur, D. R. (1961): Ticks and Disease, 445 pp., Pergamon Press, Oxford.

Balashov, Yu. S. (1968): Bloodsucking ticks (Ixodoidea)-Vectors of man and animals. Misc. Publ. Entomol. Soc. Am., 8: 161-376.

Fujimoto, K. and N. Yamaguti (1990): Ixodid ticks on vegetations and their seasonal occurrence at the upper montane to subalpine zones (ca. $600-1,800 \mathrm{~m}$ above sea level) of the Chichibu Mountains. Jpn. J. Sanit. Zool., 41: 341-346.

Fujimoto, K., N. Yamaguti and M. Takahashi (1987): Ecological studies on ixodid ticks. 2. Comparison of the seasonal occurrence of three ixodid ticks, Haemaphysalis flava, Ixodes ovatus and 1 . nipponensis in the south-western part of Saitama Prefecture. Jpn. J. Sanit. Zool., 38: 7-12 (in Japanese with English summary).

Hailkier-Sorensen, L. and K. Kragballe (1989): Multiple bites from the larvae of the tick Ixodes ricinus. A case report. Acta Derm. Venereol. (Stockh.), 69: 268-269.

Horiuchi, N. and Y. Ando (1987): Statistic analysis of human tick bites observed in our own clinic. Hifu-Byo Shinryo, 9: 557-561 (in Japanese).

Ishiguro, F., H. Iida, M. Hatano, Y. Yano and N. Takada (1992): Tick fauna and the prevalence of Lyme Borrelia in Fukui Prefecture. J. Acarol. Soc. Jpn., 1: 27-35 (in Japanese with English abstract).

Miyamoto, K. and M. Nakao (1991): Frequent occurrence of human tick bites and monthly fluctuation of ixodid ticks in Hokkaido, Japan. Jpn. J. Sanit. Zool., 42: 267-269.

Miyamoto, K., M. Nakao, N. Sato and M. Mori (1991): Isolation of Lyme disease spirochetes from ixodid tick in Hokkaido, Japan. Acta Trop., 49: 65-68.

Miyamoto, K., M. Nakao, K. Uchikawa and H. Fujita (1992a): Prevalence of Lyme borreliosis spirochetes in ixodid ticks of Japan, with special reference to a new potential vector, Ixodes ovatus (Acari: Ixodidae). J. Med. Entomol., 29: 216220.

Miyamoto, K., M. Nakao, K. Fujimoto, N. Yamaguti and E. Hori (1992b): Detection of Borrelia burgdorferi in ixodid ticks collected from the Chichibu mountainous region of Central Honshu, Japan. Jpn. J. Sanit. Zool., 43: 255258.

Nakama, H., K. Uchikawa, N. Maruchi and T. Saida (1991): A review of Lyme disease in Nagano Prefecture based on preliminary findings in 1990. Ann. Environ. Sci., Shinshu Univ., 13: 134-139 (in Japanese).

Nakao, M., K. Miyamoto, K. Uchikawa, and H. Fujita (1992): Characterization of Borrelia burgdorferi isolated from Ixodes persulcatus and Ixodes ovatus ticks in Japan. Am. J. Trop. Med. Hyg., 47: 505-511.

Saito, Y. (1959). Studies on ixodid ticks. Part I. Seasonal occurrence of ixodid ticks in Niigata Prefecture, Japan. Acta Med. Biol., 7: 193-209. Uchikawa, K., K. Muramatsu, K. Miyamoto and M. Nakao (1991): An extensive prevalence of Borrelia burgdorferi, the etiologic agent of Lyme borreliosis, in Nagano Prefecture, Japan. Jpn. J. Sanit. Zool., 42: 293-299.

Uchikawa, K. and K. Sato (1983): On tick fauna of Nagano Prefecture, Japan, with reference to distribution pattern of causative species of human tick-bite cases. Bull. Environ. Conserv. Shinshu Univ., 5: 78-82 (in Japanese with English abstract). 
Yamaguti, Y. (1980): On human tick bites, 8. Kankyo Eisei, 27(7): 24-31 (in Japanese).

Yamaguti, N. (1989): Human tick bite: Variety of tick species and increase of cases. SaishinIgaku, 44: 903-908 (in Japanese with English summary).

Yamaguti, N., V. J. Tipton, H. L. Keegan and S. Toshioka (1971): Ticks of Japan, Korea, and the Ryukyu Islands. Brigham Young Univ. Sci. Bull., Biol. Ser., 15: 1-226.

\section{㩦要}

長野県の亜高山森林带におけるシュルツェ マダニとヤマトマダ二成虫の季節消長と その生物季節との関連付け

ハタズリ法を用いてマダニ類の生急密度の高い覀高
山森林带でシュルツェマダニとヤマトマダニ成虫の季 節消長を調べるに当たり，この調查法が有効に使える 調查地点として，上高地の小梨平と美ヶ原山系の三城 を選んだ. 1991年 4 または 5 月から10月まで定期的に 生物秄節学的な資料を併せて取りながら，2 種のマダ 二類の個体数の変動を記録した. また，1992年に三城 で数回調査を追加した. その結果, シュルツェマダニ の成・若・幼虫は年 2 峰性の活動をし, 春〜夏のピー クは秋のそれより著しく大きいことが分かった，ヤマ トマダ二成虫は三城で調査時ごとに記録され，5月末 から 7 月半ばまでと 8 月末に多かったが，季節変動は 前種ほど顕著ではなかった. 小梨平や三城は有数の観 光地であり，ことに人々を引き付ける植物や昆虫が見 頃の時季に 2 種のマダ二類が両地に相当高密度で生息 していることが示された. 